\title{
RISKS OF PROPERTY VALUE APPORTIONMENT
}

\author{
Danijela llić1, \\ Vule Mizdraković
}

\author{
${ }^{1}$ National Association \\ of Valuers of Serbia, \\ Belgrade, Serbia \\ ${ }^{2}$ Singidunum University, \\ Belgrade, Serbia
}

\begin{abstract}
:
The purpose of this paper is to address the risks related to the apportionment of assessed property's market value. The valuation of property is a complex procedure which results in a unique market value of the property at particular date of valuation. The valuation can be performed for different purposes, including financial reporting, where the accountants have to recognize the value of the building or any other improvements separately from the value of the land. Therefore, professional valuers should use an adequate method to apportion the market value to these two parts. The authors will explain how this procedure should be performed and recommend the appropriate professional framework i.e. recognized valuation standards that valuers should use. The paper also presents an example of apportionment of the derived property fair value between the land and the building. In the final part of the paper, the authors will provide an opinion on the potential risks of inadequate apportion of the derived market value of the property and possible effects on financial reporting of an entity and further business operations.
\end{abstract}

Keywords:

valuation, financial reporting, building, land.

\section{INTRODUCTION}

When an entity purchases some property asset, it usually pays the total price for both the building and the land. In accounting, the purchase price is a cash outflow which is recognized as an asset if it complies with the three criteria of recognition ${ }^{1}$. However, there is no clear indication as to which amount of the purchase price is related to the value of the land and which to the building or other improvements. The same happens in the process of revaluation of properties valued based on the revaluation method using fair value. Accountants do not usually have enough expertise to separate these values, and therefore their best hope is that the valuer performs the apportionment of the total amount paid for the property. Aside from financial reporting purposes, the property owner usually likes to know where the actual value lies, in land, or in buildings or other improvements. Also, banks as financial institutions and other lenders appreciate this information because of the collaterals. If the valuation report has been challenged in court, the valuer will have difficulties in defending the assessed total value if he/she is not familiar with separate values of the property (Kaster, 1994). However, one should bear in mind that the process of total value apportionment does not involve individual valuation of market value of the land and market value of buildings and other improvements. Also, the fact that a property as a whole has a specific value does not automatically mean that separate values of land and improvements add up to the same value (Hendriks, 2005). There is even a theoretical consensus that apportionment is not possible because land and all improvements are merged together to form a new joint product (Ely, 1922; Ratcliff, 1950; Fisher, 1958).

1 Pursuant to the International Accounting Standards, the asset is a resource controlled by the entity as a result of past events, from which future economic benefits are expected to flow to the entity and which has a cost/value that can be measured with reliability. 
The paper is structured as follows. In the first part, the process of value apportionment will be described, as well as the methods prescribed by European Valuation Standards 2016 (EVS, 2016). In the second part, the hypothetical example of the hotel valuation will be presented and apportionment between the components will be shown. Before the concluding remarks presented in the final part of the paper, some concerns will be disclosed regarding inadequate apportionment of property.

\section{THE FUNDAMENTALS OF MARKET VALUE APPORTIONMENT²}

Regarding the value apportionment, the valuer can be appointed to perform apportionment of the purchase value of some property, when the client has purchased the property and tends to recognise it as an asset in financial reporting. On the other hand, the valuer can be engaged to perform the apportionment of the property fair value in the process of revaluation for the purposes of regular financial reporting activities. The purpose of the EVG 1 - Valuation for the Purpose of Financial Reporting is to provide the conceptual approach to valuation for the purposes of financial reporting for professional valuers (TEGoVA, 2016). The document provides instructions on how to conduct the valuation and which additional information should be disclosed in the case of valuation for financial purposes. Also, the document informs the professional valuers that apportionment is required in such cases. It is important to bear in mind that apportion can be performed for the market value acquired in the process of valuation, or for the purchase price acquired in the regular purchasing process. The EVIP 3 - Apportionment of Value between Land and Buildings, proposes three methods for value apportionment (TEGoVA, 2016a) as follows:

The first method advises to determine the value of unimproved or undeveloped land. Then, in order to calculate the value of the building and other improvements, the value of the land will be deducted from the total value of the property.

The second method proposes the opposite, the depreciated replacement $\operatorname{cost}^{3}$ of the building and other improvements should be obtained. The value of the land would be equal to the difference between the total value of the property and the calculated depreciated replacement cost.

The final method proposes calculating both the value of the undeveloped land and depreciated replacement cost of the building and other improvements. Those two values should be added and the proportion calculated will be applied to the total value of the property, and separate values of property components will be calculated.

2 For more information on the apportionment in theory, please refer to Hendriks (2005).

3 The EVIP 3 defines depreciated replacement cost of a building as the cost to replace it so that it can fulfil the functions for which it is used, after allowing for ageing, wear and tear and obsolescence
The first two methods belong to the residual apportionment (or fractional) theory where one value portion, either land or buildings and improvements is calculated and the rest of the value is the other part (Hendriks, 2005; Özdilek, 2012). The danger that lies within this theory is that the valuer might go wrong in determining the value of one portion of the property and that there would be no other "corrective" value. On the other hand, the third method belongs to the proportional apportionment theory which implies that there is a relationship between the value of the land and the value of the buildings and other improvements. The valuer can use the historic costs as the basis for calculating the proportion between the land and improvements. The valuer should be careful and check which assets have been recognised as land and buildings, especially if the machines and equipment have been recognised separately. Those figures could be found in the bookkeeping records or there might be enough market data.

As regards the first method, all improvements on the land should be deducted in the process of calculation of undeveloped land. Those improvements include: roads, foundations, pipelines, tanks, paved surfaces etc. Namely, the value of the unimproved land should represent solely the value that should not be depreciated. Roads, pipelines, fences and other improvements should be depreciated, as they do not have an infinite lifetime unlike the land which does. Improvements and buildings could be demolished and removed from the land and the new ones could be constructed, the land will remain even after that process. Overall, the land has some characteristics that are unique for this type of assets, as follows: indestructible, inextensible, immovable, non-reproducible, non-substitutable and non-depreciable; and it has disposes of inelastic supply, independence of existence on buildings and the value that depends on extrinsic factors (Özdilek, 2012; Gaffney \& Tideman, 1994). The opposite applies to the buildings.

It can be expected that the proportion of the value of the buildings will be very small if they are at the end of their useful life. In those cases, the value of the land will comprise the main part of the total value, maybe even above $90 \%$. Also, the land is sometimes not considered to be at its highest and best use, and could be used for other purposes. In those cases, the value of the land could be less than its market value if it is to be sold without any improvements. That value should not be used for the apportionment process, as the owner will probably continue to use the property for current purposes. One should always bear in mind that there are differences between the land value and the portion of the market value allocated to the land, just as there are differences between the land value and the value of the site (Hendriks, 2005).

If it is difficult to acquire comparable information on the value of the unimproved land, or if there are several owners of the land, it is much more practical to calculate the depreciated replacement cost of the building and other improvements. The biggest challenge in obtaining depreciated 
replacement cost is the level of the possible economic obsolescence. If there is a high degree of obsolescence, then the value of the buildings will represent a lower percentage of the total value of the property, and then it would be the case for a more up-to-date property (TEGoVA, 2016a).

One must bear in mind that the apportionment results will differ between the methods used. If the value of the building obtained by the first method is higher in comparison to the depreciated replacement cost, it is possible that the first value includes the value of intangible assets. If this is the case, special attention should be devoted to value apportionment between the building and intangibles for financial reporting purposes. Namely, intangible assets usually have much lower useful lives than buildings. It seems that the third method is most complex, but should provide more precise results. The professional valuers are advised to use at least two methods and professional judgment in order to justify the final figures, always having in mind that value apportionment is a theoretical exercise and not a true valuation. In the following part of the paper, we will provide a hypothetical example of apportionment of a complex property which includes land, buildings and other improvements.

\section{THE EXAMPLE OF VALUATION APPORTIONMENT OF THE HOTEL}

The owner of the hypothetical hotel requires the valuation of the property for financial reporting purposes. The first step in valuation and value apportionment is identification of the components of the property. The hypothetical property includes land, buildings and equipment used for commercial purposes. The client is the owner of both the land and buildings. The land area is 2,084 square meters and gross building area is 16,836 square meters. The fair value of the property equalled $\$ 56,360,000$ and income capitalisation approach has been used for obtaining this value (cost and sales comparison techniques have been used as well).

Hotels are specific forms of properties, which include the value of different type of assets: land, buildings, equipment, and intangible assets. The income capitalisation approach presumes the existence of the full functionality of the hotel, which means that the estimated value includes the land and buildings of the hotel, equipment and furniture, as well as possible contract with the brand operator (if any). In this hypothetical example, we will perform apportionment according to the first method previously explained.

The value of the land is generally obtained using the sales comparison approach, which compares the land characteristics with the comparative land that has been sold recently in similar transactions. As part of this approach, the unit of comparison must be adopted, which is usually square meter of land or the max construction gross area that can be used for improvements (CGA). If we chose CGA, we have to execute the analysis of floor area ratio (FAR) for similar parcels with the same purpose or compatible purposes. It would be ideal if they were available, systematically arranged, with this way land value statement. We have collected the following data for the hypothetical property.

In the above-given table, the sales data indicate the market value of comparable land, which ranges \$3,517-5,000 per $\mathrm{m} 2$ of land and $\$ 576$ to $\$ 704$ per CGA. In practice, the sales data are rarely readily accessible and the land characteristics are not always comprehensible. Therefore, we must exert correction on the data from the market in order to take into the account the differences in the date of the transaction, the land area, zoning and purpose, location, etc. Having in mind the characteristics of the hotel's land, we have calculated the corrected price per $\mathrm{m}^{2}$ in the amount of $\$ 5,000$. Therefore, the total land value for the land area of $2,084 \mathrm{~m}^{2}$ should be $\$ 10,420,000$.

The next step in the apportionment of the hotel's total value is obtaining the value of the equipment and furniture used for regular operations of the presumed hotel. The book value of $\$ 6,000,000$ of the equipment and furniture seemed reasonable on the date of valuation, and therefore we have adopted this value for the process of value apportion. Regarding the value of intangible assets, the owner of the hotel is not actively involved in the management of the hotel's operations. Therefore, the management gains the basic compensation for operating the hotel's activities. This component of the "business" value is written off against the base management fee. Sales and marketing costs are covered by the agreement with the operator of the hotel's brand and are recognised as operating costs. The management acquires the motivational fee for extraordinary business performances, which is also recognised as a reduction of the hotel's total

Table 1. The Floor Area Ratios for Comparative Lands

\begin{tabular}{|c|c|c|c|c|c|c|c|}
\hline $\begin{array}{c}\text { Comparative } \\
\text { lands }\end{array}$ & $\begin{array}{c}\text { Purchase price } \\
\text { in } \$\end{array}$ & $\begin{array}{l}\text { Date of the } \\
\text { transaction }\end{array}$ & FAR & Land area in $\mathrm{m}^{2}$ & CGA in $\mathrm{m}^{2}$ & Price per $\mathrm{m}^{2}$ & Price per CGA \\
\hline Sale 1 & $20,000,000$ & June 2016 & 7.1 & 4,000 & 28,400 & $\$ 5,000$ & $\$ 704$ \\
\hline Sale 2 & $12,000,000$ & June 2016 & 8.0 & 2,500 & 20,000 & $\$ 4,800$ & $\$ 600$ \\
\hline Sale 3 & $21,100,000$ & August 2016 & 6.1 & 6,000 & 36,600 & $\$ 3,517$ & $\$ 576$ \\
\hline
\end{tabular}


revenue. Therefore, it can be concluded that there is no intangible component of the hotel's total value.

Finally, we will discuss the value of the hotel's buildings. Usually, the construction cost of the hotel's building is determined using the tables of estimated costs of hotel development, which are provided by internationally recognized companies, such as: HVS, STR Global, EC Harris, and Marshall Swift/Boeckh etc. The practice has shown that engineers use these manuals, which provide the average construction costs and their engineering knowledge and experience is used in correcting the data shown in the manuals. The analysis of the reproduction costs position by position, for several thousand positions for an average hotel, would be quite time-consuming and require teamwork, which would go beyond the scope of the apportionment process. To allocate the value of the buildings, we believe that the data on the development of costs for five-star hotels in European cities, which are to be found in the HVS 2010/1, are sufficient and reliable (Sahlins, 2011).

Table 2. The Calculation of the Value of the Hotel's Separate Components

\begin{tabular}{|c|c|c|c|}
\hline Items & Values in $\$$ & $\begin{array}{c}\text { Percentage in } \\
\text { total value }\end{array}$ & $\begin{array}{c}\text { International } \\
\text { average }\end{array}$ \\
\hline $\begin{array}{l}\text { Hotel's total } \\
\text { value (Income } \\
\text { approach) }\end{array}$ & $56,360,000$ & $100 \%$ & I \\
\hline Land value & $10,420,000$ & $18.49 \%$ & $10-17 \%$ \\
\hline $\begin{array}{l}\text { Value of } \\
\text { equipment } \\
\text { and furniture }\end{array}$ & $6,000,000$ & $10.65 \%$ & about $11 \%$ \\
\hline $\begin{array}{l}\text { Buildings } \\
\text { value }\end{array}$ & $39,940,000$ & $70.86 \%$ & $60-65 \%$ \\
\hline
\end{tabular}

The hypothetical hotel has 218 rooms with the gross area of $16,836 \mathrm{~m}^{2}$. The average construction costs for this type of five-star hotel, without the swimming pool, with similar furniture and equipment and a wellness centre, amount to approximately $\$ 160,000$ per room (Sahlins, 2011). If we adopt this average cost, the total value of the building with 218 rooms would be about $\$ 35,000,000$, which roughly corresponds to the value disclosed above. Also, the proportion of buildings in total value of $70.86 \%$ corresponds to the results of the studies performed on larger research samples. For example, Guerin (2000) used the data for 7.357 residential sales in Peterborough in Canada and found out that $31.2 \%$ represents the portion of the land and $68.8 \%$ the building portion. With similar amount of data from Edmonton in Canada, Gloudemans (2002) estimated the average total property value, where land represents $35.6 \%$ and buildings $64.4 \%$ of the total value.

\section{THE EFFECTS OF INADEQUATE VALUATION APPORTIONMENT ON FINANCIAL REPORTING}

Inadequate apportion of property market value can have different financial effects on financial reporting and disclosed financial results. Allocation of higher value on the land could lead to higher financial performances and lower depreciation costs, since the land is not depreciable. However, this could result in higher total property tax, since the buildings have definite useful life unlike the land. The property tax is an obligation related to the owning of the property, not trading, which would be another type of tax. Out of all EU members, France is the only member that has net property tax. Namely, the total value of property is decreased for any possible liabilities on the property and the tax is paid only if the net value exceeds 790,000 EUR. The tax relief of $30 \%$ of the value is allowed, and some business assets, antiques, arts, insurance policies are exempt from taxation (Kesner-Škreb, 2009).

There is no such tax relief in the Republic of Serbia. Namely, the taxpayers who use fair value as the basis for property valuation in their financial reporting in accordance with IAS and IFRS and have their accounting policies adopted on the basis of fair value, use fair value recorded on the last day of the business year in the current year as the basis for property tax calculation (National Assembly of the Republic of Serbia, 2014). Also, investors probably attribute different levels of risk to the land investments and different levels to the investments in buildings and other improvements. Therefore, they would probably prefer to know which part of their capital is invested in land and improvements (Hendriks, 2005). Furthermore, in courts, when the valuer is challenged, it will be difficult to defend the market value of the property if he/she is not familiar with the characteristics and separate values of the land and buildings and other improvements.

\section{CONCLUSIONS}

It can be concluded that apportionment plays an important role in the valuation process, which can be associated with different types of risks. However, this process should not be performed by the client, especially when valuation has been performed for financial reporting purposes, as professional valuers will most likely perform the process more accurately. We hope that this paper has laid out the basics of this concept and that it will provide assistance to professional valuers in Serbia when determining separate values more accurately. This will result in more accurate tax calculation, more reliable financial reporting and potential investors and municipal authorities will benefit from adequate market value apportionment. Further research in this field could focus on the average proportion of the total value attributed to the land and buildings and other improvements for residential and commercial properties in the Republic of Serbia, as such data is not available in our country. 


\section{REFERENCES}

Ely, T. (1922). Research in Land and Public Utility Economics. Land Economics, 1(1), 1-5.

Fisher, E. (1958). Economic Aspects of Urban Land Use Patterns. The Journal of Industrial Economics, 6(3), 379-386.

Gaffney, M., \& Tideman, N. (1994). Land and Taxation. London: Shepheard-Walwyn.

Gloudemans, R. (2002). An Empirical Analysis of the Incidence of Location on Land and Building Values. Retrieved from Researchgate: https://www.researchgate.net/publication/260300263_An_Empirical_Analysis_of_the_Incidence_of_Location_on_Land_and_Building_Values

Guerin, B. (2000). MRA Model Development Using Vacant Land and Improved Property in a Single Valuation Model. Assessment Journal, 7(4), 27-34.

Hendriks, D. (2005). Apportionment in Property Valuation: Should We Separate the Inseparable? Journal of Property Investment \& Finance, 23(5), 455-470.

Kaster, L. (1994). Disposition of Real Estate: Separating land from Building. 16th Annual Conference on Federal Taxation of Real Estate Transactions. New York: New York University.
Kesner-Škreb, M. (2009). Što sve treba znati o oporezivanju nekretnina. Povremeno glasilo instituta za javne financije, 46(1), 1-6.

National Assembly of the Republic of Serbia. (2014). Law on the Property Tax of the Republic of Serbia. Retrieved from Tax Administartion of the Republic of Serbia: http://www. poreskauprava.gov.rs/sr/pravna-lica/pregled-propisa/zakoni/323/zakon-o-porezima-na-imovinu.html?print=true

Özdilek, Ü. (2012). An Overview of the Enquiries on the Issue of Apportionment of Value between Land and Improvements. Journal of Property Research, 29(1), 69-84.

Ratcliff, R. (1950). Net Income Can't be Split. The Appraisal Journal, 18(1), 168-172.

Sahlins, E. (2011, January). HVS Hotel Development Cost Survey 2010. Retrieved August 9, 2016, from HVS: https://www. hvs.com/article/5061-hvs-hotel-development-cost-survey-2010

TEGoVA. (2016). European Valuation Standards 2016. Retrieved from TEGoVA: http://www.tegova.org/data/bin/ a5738793c0c61b_EVS_2016.pdf

TEGoVA. (2016a). Apportionment of Value between Land and Buildings. Retrieved from TEGoVA: http://www.tegova. org/data/bin/a5738793c0c61b_EVS_2016.pdf

\section{POSLEDICE NEADEKVATNE ALOKACIJE VREDNOSTI NEKRETNINA}

\footnotetext{
Apstrakt:

U ovom radu, analiziraćemo rizik koji se javlja usled neadekvatne alokacije procenjene tržišne vrednosti nekretnina, kao i posledice vezane za takvu alokaciju. Procena vrednosti nekretnina predstavlja složen postupak koji vodi ka jedinstvenoj tržišnoj vrednosti imovine na dan procene. Procena se može obaviti za različite namene, uključujući i finansijsko izveštavanje, gde bi računovođe trebalo da razdvoje vrednost građevinskog objekta od vrednosti zemljišta ili bilo kog tehničkog unapređenja koje se nalazi na njemu. Stoga, profesionalni procenitelji bi trebalo bi da koriste adekvatan način raspodele tržišne vrednosti na ova dva dela. Objasnićemo kako bi trebalo da se sprovodi ovaj postupak i daćemo preporuku profesionalne regulative, odnosno priznatih standarda procene koje bi procenitelji trebalo da koriste u praksi. U radu ćemo predstaviti i primer alokacije fer vrednosti predmetne nekretnine na zemljište i građevinske objekte. U završnom delu rada iznosi se mišljenje autora u vezi sa potencijalnim rizicima, koji se mogu javiti usled neadekvatne alokacije alocirane tržišne vrednosti nekretnina i mogućim posledicama na finansijsko izveštavanje pravnog lica i dalje poslovanje.
}

\section{Ključne reči:}

procenjivanje, finansijsko izveštavanje, građevinski objekat, zemljište. 